Article

\title{
Valence Secession? Voting Shocks and Independence Support in Scotland
}

\author{
Robert Liñeira \\ School of Social and Political Sciences, University of Glasgow, UK; E-Mail: robert.lineira@glasgow.ac.uk
}

Submitted: 30 May 2021 | Accepted: 30 August 2021 | Published: 10 December 2021

\begin{abstract}
National identifications, cues from political actors, and cost-benefit calculations have been pointed as the main determinants of secession preferences. However, a recent surge in independence support in Scotland suggests that abrupt political changes may also affect these preferences: Brexit and the differentiated management of the Covid-19 pandemic by the UK and the Scottish governments are named as causes of the first independence sustained majority registered by polling in Scotland. In this article, I discuss how voting shocks may affect the levels of support for independence, revise the evidence that sustains these claims, and analyse how they have changed the profile of the pro-independence voter. The effect of these questions has substantial implications for a possible second independence referendum in Scotland, as well as for the broader debate on the sources of secession support.
\end{abstract}

\section{Keywords}

Brexit; Covid-19; pandemic; independence referendums; Scotland

\section{Issue}

This article is part of the issue "Secessionism in Liberal Democracies: What Do We Really Know About the Explanations of Secessionism?" edited by Ferran Requejo (Pompeu Fabra University, Spain) and Marc Sanjaume-Calvet (Pompeu Fabra University, Spain / Open University of Catalonia, Spain).

(C) 2021 by the author; licensee Cogitatio (Lisbon, Portugal). This article is licensed under a Creative Commons Attribution 4.0 International License (CC BY).

\section{Introduction}

National identifications, cues from political parties and leaders, and cost-benefit calculations have been pointed as the main determinants of individual preferences about secession. These factors tend to remain stable and, with them, preferences about secession. However, independence support has changed dramatically during the last decade in Scotland coinciding with three voting shocks - the 2014 Scotland independence referendum, the 2016 EU membership referendum, and the Covid-19 pandemic - that may have changed not just the levels of support for independence, but also the relationship between secession determinants and secession preferences.

In this article, I assess the determinants of secession support paying special attention to major political events such as the Brexit rupture and the crisis triggered by the Covid-19 pandemic, events with the potential to prompt sections of the population to update their views on secession. Brexit can reinforce the idea of a democratic deficit due to the difference in preferences between Scotland and the rest of the UK evidenced by the outcome of the 2016 EU membership referendum, whereas the different handling of the pandemic by the Scottish and UK government may help build support for a valence secession, that is, an independence backing grounded in the view that Scotland would govern itself more effectively as an independent country. Apart from these narratives with a potential direct effect on secession preferences, both shocks can also moderate the effect of secession determinants on secession support.

The article proceeds as follows. First, I present the factors behind secession preferences across sub-state polities and discuss why the changes introduced by Brexit and the Covid-19 pandemic may have switched the independence choice of a segment of Scottish voters. Second, I discuss the relevance of the Scottish case and present the data. Third, I assess the effect of the 2014 Scotland independence referendum and the existing evidence on the effect of Brexit and the pandemic on secession support, as well as analyse the change in the profile of the 
pro-independence voter. Finally, I discuss the findings' implications for the Scottish case and the broader debate on the individual determinants of secession preferences.

\section{Theory}

The existence of different national communities and projects is the defining characteristic of multi-national polities where different national identities co-exist. State-wide identities are mainly promoted by central state institutions while sub-state-wide identities are mobilised by sub-state nationalist movements that demand sovereignty in the form of self-government institutions or full secession (Lluch, 2014). The existence of a distinct national identity in a sub-state territory does not necessarily translate into demands for self-government and secession. However, such claims have rarely existed in history without the presence of a distinctive group identity (Sorens, 2005, 2012).

Citizens within the multi-national sub-state territories develop identifications with the alternative national communities. National identifications provide individuals with an affective link to a national community, a sense of belonging, pride, and self-esteem (Tajfel, 1974). These national identifications may be exclusive or nested (Medrano \& Gutiérrez, 2001) and may vary in intensity (Hierro, 2012). They are mainly the product of socialisation and past experiences hence they rarely change over short term periods (Dalton, 1999, p. 74; Hierro, 2012). Due to their stability, they constitute one of the strongest determinants of sovereignty preferences in those territories where the national community of reference is a contested and salient issue. Evidence from Quebec (Blais \& Nadeau, 1992), the Basque Country (Serrano, 2020), Catalonia (Guinjoan, 2021), and Scotland (Bond, 2015) proves so.

Party cues are the second source of constitutional preferences. Public opinion is cued by political elites and parties constitute the most important political organization that link elites to the people. Decades of research have persistently shown that parties provide citizens with stances and arguments that help them to establish their preferences (Zaller, 1992). Again, the stable nature of parties helps them to perform this role. Unlike more transient elements such as issues and candidates, parties give continuity and structure to the political debate. This enables citizens to develop a lasting bond with some party (or, conversely, an enduring dislike) that acts as a perceptual screen through which they follow the political process (Campbell et al., 1960). In multi-national polities the salience of the constitutional issue affects this partisanship-some individuals select their preferred party because of its constitutional position rather than the other way around-though the exogenous impact of partisanship on secession support is well-established (Clarke et al., 2004; Liñeira \& Henderson, 2021). The impact of partisanship on secession preferences is particularly clear in secession refer- endums when parties and their leaders become one of the main sources of information during the campaign (de Vreese, 2007; LeDuc, 2003).

Cost-benefit calculations constitute the third source of constitutional preferences identified by Hooghe and Marks (2005). Calculations differ in style and mood from enduring predispositions such as national and party identifications: The latter refer to affects and the emotional side of politics, whereas calculations relate to its rational aspect. However, this does not mean that these kinds of thoughts are unrelated. Political psychology shows that individuals frequently engage in motivated reasoning by relying on identifications and emotions to produce arguments that favour the conclusion they want to believe rather than the one that best reflects the evidence (Lodge \& Taber, 2013; Redlawsk, 2002).

Economic considerations are the main cost-benefit calculation discussed by the literature on secession. At the macro-level, the relative economic status of the sub-state territory vis-à-vis the whole state determines the economic discourse of sub-state nationalism (Gourevitch, 1979). The dominant prediction is that regions or groups that are better off than the rest of the country will have a higher likelihood of demanding secession (Bartkus, 1999; Hechter, 2000). Two mechanisms would produce this relationship. First, as they often subsidise poorer regions, secession means that more disposable resources would be available due to the elimination of fiscal imbalances (Sambanis \& Milanovic, 2014). Second, secession would allow sub-state territories to provide public goods more efficiently since a smaller community translates into an increased homogeneity of preferences (Alesina \& Spolaore, 2005).

The impact of cost-benefit calculations on secession preferences is difficult to assess. As mentioned, there is always the possibility that citizens would express a view congruent with their existing preferences when asked about their expectations on the economic consequences of independence, that is, economic expectations could be mere rationalizations of prior preferences (Howe, 1998; Mendelsohn, 2003). However, a survey experiment indicates that economic considerations may play an independent role even if this impact is smaller than the one exerted by national and partisan identifications (Muñoz \& Tormos, 2015). Economic considerations are particularly salient to citizens with ambivalent national and partisan identifications (Muñoz \& Tormos, 2015), but also to those exposed to economic disruption in the event of secession (Hierro \& Queralt, 2021). Even if they are less relevant than other sources of secession preferences, the marginal impact of economic cost-benefit analyses can be crucial when secession is decided in an independence referendum and none of the options shows a clear lead in the polls during the campaign. Different accounts of the independence referendums in Quebec and Scotland point to the economic question as crucial to the final outcome (Blais et al., 1995; Curtice, 2015b). 
National identifications, partisanship, and costbenefit calculations make a comprehensive list of the substantive elements that condition preferences about the territorial constitution across sub-state territories. Other elements, however, may affect the decision to support independence. The literature has particularly underlined the role that individuals' attitudes towards risk play in the choice, particularly when the independence question is determined in a decisive vote. Choosing a ballot involves gambling on what is offered and promised with that option, hence the individuals' attitudes towards taking risks can affect the vote choice, particularly when the stakes are high.

Independence referendums are salient votes that inevitably propose a change of uncertain consequences. The independence decision is a high-stakes one because it has comprehensive consequences for the political system. It affects the borders of the polity and the boundaries of the political community; it implies drafting a new constitution and introducing changes to the institutional regime; it will probably affect the party system and the politics of the sub-state territory. The saliency of the issue facilitates that the voter becomes familiar with some of these questions, but uncertainty is prominent and unavoidable. First, because the electorate can rely on few precedents since independence referendums are rare in the context of consolidated democracies. Second, and most importantly, because independence specifics depend on post-referendum negotiations between the government of the seceding state and the government of the host state, the outcome of which is unknown before the vote.

Faced with uncertain outcomes, risk-averse voters may disproportionally lean against change, creating a powerful advantage for the status quo (Berger et al., 2000; Christin et al., 2002). At elections, risk-averse voters avoid candidates with ambiguous issue positions (Tomz \& Van Houweling, 2009), challengers that face experienced incumbents (Eckles et al., 2013; Morgenstern \& Zechmeister, 2001), and candidates who argue for a departure from the status quo (Kam \& Simas, 2010). It is not surprising, therefore, that opposition to independence is higher among risk-averse voters (Liñeira \& Henderson, 2021; Nadeau et al., 1999). Risk attitudes particularly affect the vote choice of those less politically aware and, hence, more uncertain about the consequences of secession (Liñeira \& Henderson, 2021).

These four types of considerations-national identifications, partisanship, cost-benefit economic calculations, and attitudes towards risk-constitute the fundamental equation that explains secession preferences across substate territories. It is mainly through changes in any of these factors-either a change in their aggregate levels or a change in their relationship to secession supportthat we should expect a surge or a decline in the support for independence. These factors do not change easily so stability is the norm. In Scotland, secession preferences seemed to have stabilized after the shock produced by the 2014 independence referendum, but a recent surge in independence support suggests that two new external shocks may affect secession preferences: Brexit and the Covid-19 pandemic.

Electoral shocks have been recently defined as major political events that have the potential to prompt large sections of the population to update their political evaluations and party preferences (Fieldhouse et al., 2019). According to Fieldhouse and collaborators, electoral shocks have three characteristics: (1) They represent a sharp and often unanticipated change to the status quo outside the normal course of politics; (2) they are highly salient and manifest over prolonged periods, so they have the potential to be noticed and recognised even by people who are uninterested in politics and by those who might otherwise select into information that fits their partisan predispositions; and (3) they are politically relevant and have the potential to change how parties are perceived, the people's vote and the party system. Though electoral shocks might not have major consequences, they should be able to produce political change in the short and long term.

This conception of electoral shocks can be used to include all external events that affect issues such as secession that may be relevant not just for elections and party politics, but also for other kinds of votes such as referendums. I will refer to events such as Brexit and the pandemic as voting shocks. The mechanisms by which these voting shocks led to secession preference switching may vary. Fieldhouse et al. (2019) identify three ways in which they can affect the vote: They can either change the perceptions of competence, the salience of issues and dimensions, or the image of the parties. I will now discuss the potential mechanisms by which Britain's exit of the EU and the pandemic may have a direct or a moderator effect on secession preferences.

EU membership is a position issue orthogonal to the question of Scotland's independence. There is no logical connection between the two issues: A person can support or oppose independence combined with being in favour or against EU membership. When voters in Scotland went to the polls to give their verdict on independence in 2014, their view about EU membership made little difference to how they voted: Those who were sceptical about Britain's membership of the EU were no more or no less likely than those who were more sympathetic to the organization to vote Yes (Curtice, 2015a).

Brexit potentially changes this. It is a major political rupture that taps onto several secession determinants that may affect the individual's position on secession. First, independence out of the EU affects the cost-benefit calculations of independence. The direction of the effect depends on the general economic impact of Brexit and may vary across individuals depending on their skills and the sector in which they are employed-more skilled workers and those occupied in sectors specializing in foreign markets are more affected by the decision to close the UK economy. Second, the economic consequences 
of Brexit are uncertain which may affect the secession preferences of risk-averse voters. These two mechanisms would modify the impact of some of the secession determinants mentioned before.

However, Brexit also affects sovereignty narratives which constitutes a distinct mechanism with a direct effect on secession preferences. Scotland voted in favour of staying in the EU in the 2016 referendum by 62 per cent, but it ended up out of the EU because leaving the EU won in the UK as whole. Scotland's wishes were overturned by the prevalent views in the rest of the UK. As such, the historic "democratic deficit" which had ultimately entrenched support for a distinct Scottish Parliament in the 1980s and 1990s (Paterson et al., 2001) could now translate into a new reason to support independence, producing a surge in secession support.

The other electoral shock came later with the outbreak of the Covid-19 pandemic, which immediately became the main political issue. Unlike the EU membership divide, the pandemic is a valence issue: Rather than stances on different policy goals, the Covid crisis involves judgements about how effectively the different parties pursue the widely accepted goal of halting the spread of the virus while minimising the economic consequences. It is a salient issue with the potential to affect secession determinants and secession preferences in Scotland.

The effects of the pandemic on secession preferences may also be direct and indirect. Indirect effects include the moderation role that the Covid-19 crisis might have had on the relationship between secession determinants and secession preferences. For instance, Covid can change people's expectations about the economic consequences of independence and other types of cost-benefit calculations. However, the multilevel nature of the UK government also taps into a dimension that potentially has a genuine and direct effect on secession views: The pandemic has highlighted the capacity of the Scottish government to make different decisions in a devolved area of jurisdiction, with the Scottish government following a strategy that seemed to privilege health considerations which contrasted with the UK government strategy that seemed to favour the economy. As we will see, the Scottish public perceived such a difference and was closely aligned with the strategy pursued by the Scottish government. Unlike other policy divergences between the Scottish and UK governments such as university tuition fees and prescription charges (Curtice, 2006), this one affects a highly salient issue, one that has the potential to create the view among the public that Scotland would have governed itself more effectively as an independent country. As such, it constitutes an alternative potential driver of secession preferences.

\section{Data and Method}

The 2014 Scottish independence referendum is an exemplary and prototypical case of the rare phenomenon of votes to secede from a consolidated democracy.
Despite their long history-the first reference to an independence referendum dates back to the 14th century (Mattern, 2019, p. 37) -and the fact that they have been widely used in the case of secession (Qvortrup, 2014, pp. 56-58), independence referendums in established democracies such as the Quebec and the Scotland votes are rare. Even within this tiny category, the Scotland referendum stands out as exceptional. The questions asked in the 1980 and 1995 Quebec votes were ambiguous, and though the Canadian government participated in the campaigns, the legitimacy of the votes was questioned. By contrast, the Edinburgh Agreement between the UK and the Scottish governments allowed a referendum process with no legitimacy queries. It also resulted in a very clear referendum question-"Should Scotland be an independent country?"-and a clear decision rule: Independence or union would be decided by plurality vote.

The 2014 Scottish campaign was dominated by sovereignty and economic concerns. The proindependence campaign framed independence as an opportunity to pursue policy goals without the interference of the UK government based in London, allowing the Scottish government to pursue left-of-centre policies that reflect the pro-social justice values that are often perceived by Scots themselves to distinguish the Scottish electorate from the UK one (Henderson, 2014). The efficiency argument and the more disposable resources claim were also used: Independence would allow Scotland to follow strategies that suited its needs and retain oil revenues (Scottish Government, 2013). By contrast, the pro-union campaign warned that independence would end the currency union and the financial support of the Bank of England. It suggested that Scotland might not be able to join the EU or, if it became a new EU member, would be forced to join the Euro. It also argued that independence would damage the Scottish economy and finances (Keating, 2017).

I will use two survey projects to analyse secession preferences in Scotland. First, the Scottish Social Attitudes Survey (SSAS). It is a cross-sectional study particularly suited to analyse long-term trends because it has been tracking political attitudes yearly since 1999 . It contains a five-option question on different constitutional alternatives that has been asked regularly throughout the two decades of devolution. Second, the British Election Study Internet Panel (BESIP), which contains a large Scottish sample and a specific module of questions (Fieldhouse et al., 2020). As a panel survey, it is particularly suited to analyse short term changes such as the one produced by the pandemic outbreak.

\section{Evidence}

\subsection{The Impact of the 2014 Independence Referendum}

The 2014 independence referendum broke the Scottish politics mould. The campaign legitimised the option of 
independence and mobilised unprecedented numbers of people behind a previously minority cause (Henderson \& Mitchell, 2018). As a result, the Scottish electorate realigned around the independence issue. Since the referendum, the Scottish National Party (SNP) nearmonopoly over Yes voters has delivered a series of electoral victories at Westminster and Holyrood alike, largely at Scottish Labour's expense. The Scottish Conservatives have also benefitted. Their unionist credentials place them as the best agent to resist the SNP's separatist aspirations. They have become the official opposition at Holyrood in 2016 (Johns \& Mitchell, 2016) and 2021.

This realignment and its impact on the relationship between secession determinants and secession preferences is summarized in Table 1. It shows the percentage of support for independence before and at the end of the referendum campaign, by the three main determinants of secession preferences: national identifications, partisanship, and perceptions of the economic consequences of independence. The pattern is clear: The referendum debate made the relationship between national identity and independence support much stronger. Those who identify themselves as only Scottish and more Scottish than British increased their support for independence, whereas the other identity groups showed little change, except for the small group of those who identify exclusively with Britain.

Partisanship and Yes support also reinforced its relationship: Those who identified with the SNP and the Greens increased dramatically their support for independence. The referendum led a significant number of voters to align their Scottish Parliament vote to their position on independence. Before 2014, some voters selected an SNP ballot at Scottish Parliament elections but voted otherwise at UK Parliament elections and did not support independence. A significant amount of them switched their support to the SNP at general elections and in favour of secession because of the independence debate. The referendum forced the electorate to choose from a Yes and a No vote for independence, breaking the traditional mould of Scottish politics. The alternation between Labour and SNP as the largest party at each election level, and the dual voting behind this electoral change, seems now something of the past (Henderson \& Mitchell, 2018).

A similar pattern emerges when we analyse the connection between economic calculations and independence support. Before the campaign, those who thought independence would result in a better economy were less inclined to support independence than by the end of the campaign. The main effect of the campaign was not one of persuasion but one of reinforcing the link between attitudes, calculations, and the vote (Curtice, 2015a; Liñeira et al., 2017). As election campaigns frequently do, the referendum campaign provided voters with an opportunity to learn more about the subject and helped them to crystallize their updated views in the ballot box (Erikson \& Wlezien, 2012; Gelman \& King, 1993).

The referendum also made mainstream the proindependence choice. Before the referendum, the support for independence fluctuated between 23 and 32 per cent and according to the five-option question

Table 1. Secession determinants and support for independence before and after the 2014 Scotland independence referendum.

\begin{tabular}{|c|c|c|c|}
\hline & 2012 & 2014 & Change \\
\hline \multicolumn{4}{|l|}{ National identity } \\
\hline Only Scottish & 46 & 60 & +14 \\
\hline More Scottish than British & 23 & 43 & +20 \\
\hline Equally Scottish and British & 11 & 11 & 0 \\
\hline More British than Scottish & 12 & 11 & -1 \\
\hline Only British & 4 & 10 & +6 \\
\hline \multicolumn{4}{|l|}{ Party identification } \\
\hline SNP & 57 & 78 & +21 \\
\hline Green & 17 & 44 & +27 \\
\hline Labour & 15 & 21 & +6 \\
\hline Conservative & 5 & 5 & 0 \\
\hline Liberal Democrat & 9 & 14 & +5 \\
\hline \multicolumn{4}{|c|}{ Evaluations of the economic consequences of independence } \\
\hline A lot better & 78 & 88 & +10 \\
\hline A little better & 46 & 81 & +35 \\
\hline No difference & 32 & 35 & +3 \\
\hline A little worse & 10 & 11 & +1 \\
\hline A lot worse & 4 & 3 & -1 \\
\hline
\end{tabular}

Notes: Independence support is measured using the five-option question on constitutional preferences, not the binary referendum question; data for 2012 were collected between July and October 2012, while those for 2014 were collected between May and August 2014. Source: SSAS (ScotCen Social Research, 2013, 2016). 
on constitutional preferences asked between 1999 and 2012 by the SSAS (Curtice, 2015a). Figure 1 shows the evolution of independence support since 2013, when commercial polling started to gather data using the binary question used in the 2014 referendum. From 2013 to referendum day, independence showed a steady rise that was particularly acute during the last weeks of the campaign (Liñeira et al., 2017, p. 169; McGann et al., 2019 , p. 54). The rise was fed by undecideds disproportionally leaning to Yes and, to a lesser extent, by former No voters persuaded to change.

After the independence referendum, the gap between No and Yes closed marginally, but Yes was never ahead. The EU membership referendum did not change this. Despite the collective will of Scotland being defeated in the Brexit referendum, Figure 1 does not show a remarkable change in the aftermath of the EU referendum. Actually, the gap in favour of No increased during the months after the Brexit vote. The 2017 general election resulted in a hung Parliament that was unable to build a majority for a withdrawal agreement with the EU or any alternative course of action. The stalemate intensified the debate about Brexit and the issue came to dominate the UK's political agenda.

Before the 2019 general election-that crystalized the expected Conservative majority-opinion polls had already shown a rise in independence support. The gap between No and Yes closed in the summer of 2019 (Curtice, 2019), but it was only in the summer of 2020, after the outbreak of the coronavirus pandemic, that Yes became ahead in the polls. Autumn 2020 registered the highest support for independence ever: Polls put Yes up to 58 per cent, with average support of 54 per cent (Curtice, 2020). Polls from early 2021 still place Yes ahead, though its support slightly declined jointly with the speedy UK vaccine rollout programme (Curtice, 2021).

\subsection{The Impact of the Brexit Referendum}

Though the EU membership referendum did not immediately change the aggregate support for Scotland's independence, it changed the nature of the independence debate (Curtice \& Montagu, 2020). Since 2016 the debate on secession has come to be framed as a choice between an independent Scotland that would be aiming to re-join the EU and a Scotland that is part of a UK out of the EU. This would seem to encourage voters to compare what they think would be the consequences of independence with what they consider will happen as a result of leaving the EU.

Though the Brexit referendum did not boost support for independence, there were indications that the Europhile and the pro-independence outlooks were bundling together. Following Phillips et al. (2018,

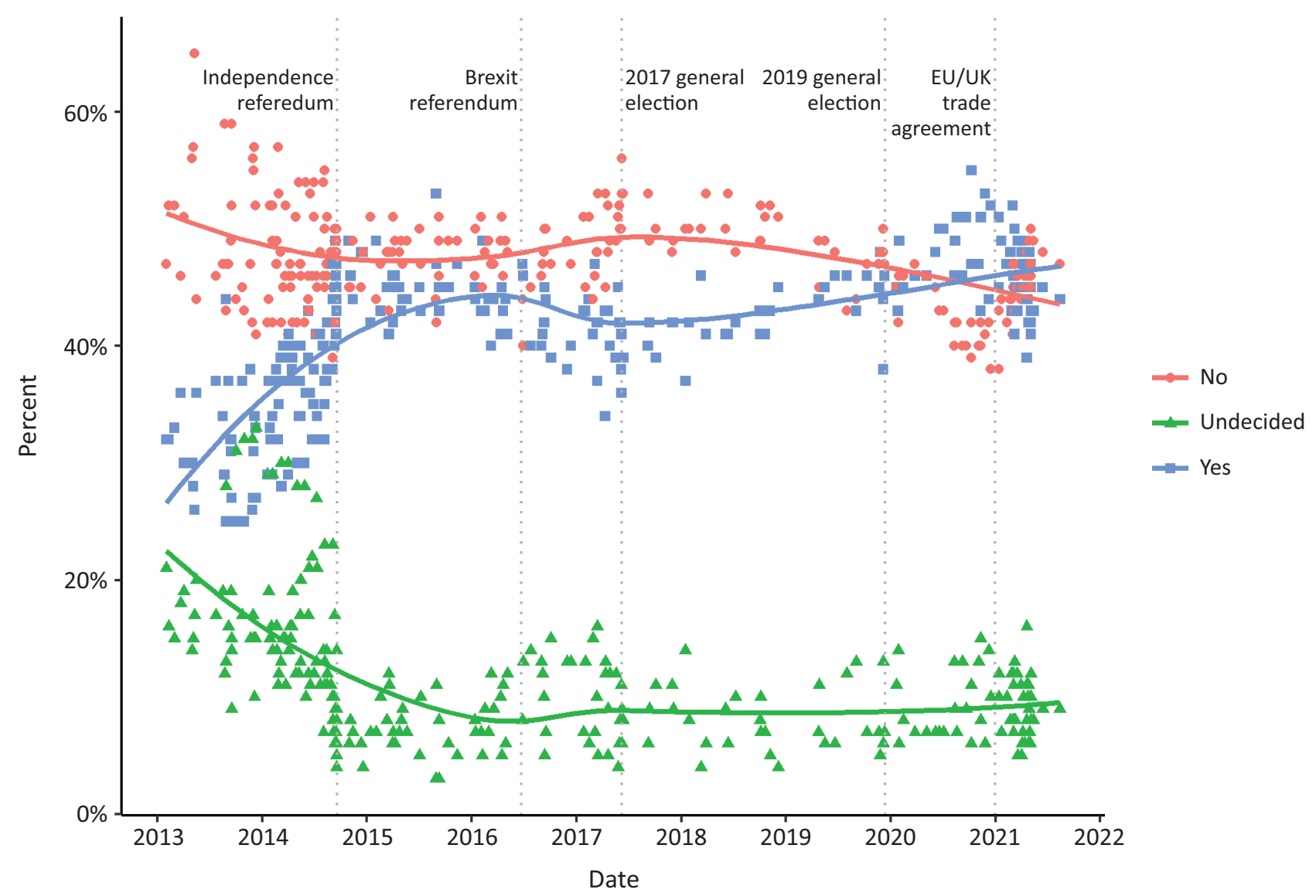

Figure 1. Independence voting intentions in Scotland, 2013-2021. Source: What Scotland Thinks (n.d.). 
pp. 196-225), Figure 2 classifies respondents into Eurosceptics and Europhiles and tracks their respective support for independence. Before the referendum, both groups showed very similar levels of independence support. However, a gap opened in 2016 and it has widened every year since.

Initially, Brexit produced changes in secession preferences of similar size that cancelled each other. The switch to pro-independence positions by some of those who voted Remain was initially counterbalanced by increased opposition to secession among those who voted Leave (Curtice \& Montagu, 2020; Fieldhouse et al., 2019, pp. 153-161). Brexit cross-cuts the independence referendum debate creating four constitutional groups: Yes/Remain, Yes/Leave, No/Remain, and No/Leave (Mitchell \& Henderson, 2020). According to the latest BESIP wave, the No/Remain is the largest onethe group that represented the status quo until the UK left the EU in 2020-with 38 per cent. Unsurprisingly, given Scotland's sizeable Remain majority at the 2016 EU referendum, Yes/Remain is the second-largest constituency, with 24 per cent of the electorate, followed closely by the No/Leave group that comprises 23 per cent of the electorate. Finally, the smallest group is the Yes/Leave constituency which gathers 13 per cent of the electorate.

The current configuration of this cross-constitutional cleavage leaves two of these groups in contradictory positions. Whereas the Yes/Remain group is mainly represented by the SNP and its independence within the EU project, the Scottish Conservatives stand for the No/Leave constituency with its proposal of a UK union out of the EU. The other two groups are unrepresented by the current political landscape and their members may feel forced to choose between their position on Scotland's secession and their EU membership stance. Table 2 shows the voting intention for independence of these four groups in June 2020 . The data show no contradiction in the Yes/Remain and the No/Leave groups: They show overwhelming loyalty rates to their secession preference of 83 and 86 per cent. Loyalty rates are, however, weaker in the cross-pressured groups: Around 1 out of 4 have switched to the other side of the independence debate in the Yes/Leave and No/Remain groups. This defection rate, plus the fact that the latter group is the largest constituency, is behind the pro-independence surge shown in Figure 1.

\subsection{The Impact of the Covid-19 Pandemic}

Table 3 shows the public's judgment on the handling of the first wave of the pandemic by the Scottish and British governments. The data show a huge difference in the assessments. Only 19 per cent of the Scottish public thought that the UK government had handled the pandemic very or fairly well, whereas a clear majority of 63 per cent had a negative view. By contrast, the Scottish government handling received more positive judgements: 58 per cent valued it positively and only 23 per cent had a negative assessment.

During the first weeks of the pandemic, there was a heated debate about a potential trade-off between taking decisions prioritizing health or the economy. Faced with a pro-health vs. a pro-economy dilemma, the Scottish public thought that their pro-health stance was much better represented by the Scottish government.

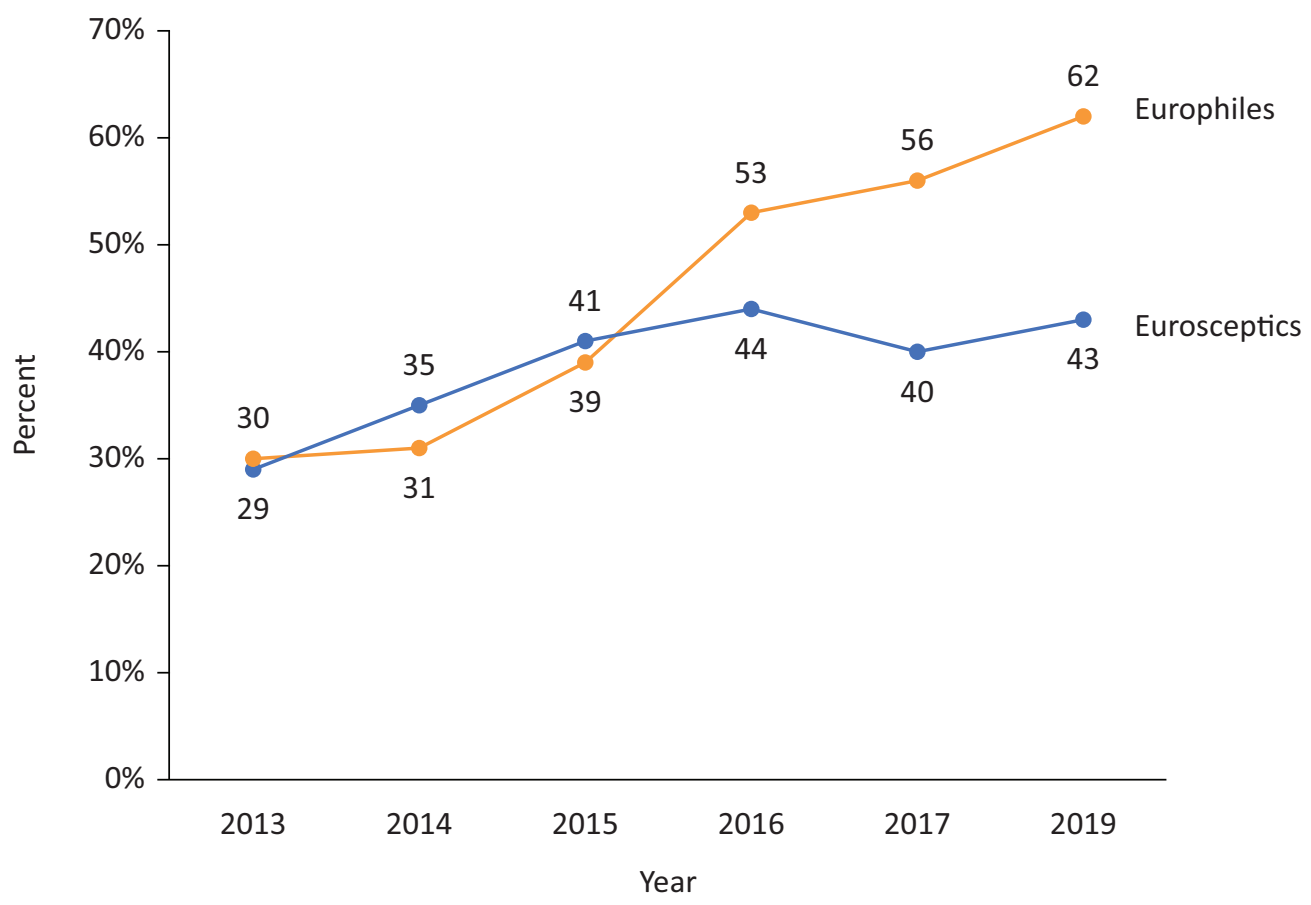

Figure 2. Independence support of Europhiles and Eurosceptics, 2013-2019. Source: Curtice and Montagu (2020, p. 17). 
Table 2. Independence vote intention by constitutional preferences, 2020.

\begin{tabular}{lcccr}
\hline & Yes/Leave & No/Remain & Yes/Remain & No/Leave \\
\hline Yes & 60 & 23 & 83 & 8 \\
No & 27 & 64 & 9 & 86 \\
Abstain/Do not know & 14 & 14 & 7 & 6 \\
(N) & $(324)$ & $(862)$ & $(606)$ & $(446)$ \\
\hline
\end{tabular}

Note: Scottish respondents only. Source: BESIP, wave 20-June 2020 (Fieldhouse et al., 2020).

Table 3. Perceptions of handling of the coronavirus crisis by the UK and Scottish governments.

\begin{tabular}{lcc}
\hline & $\begin{array}{c}\text { How well has the UK Government } \\
\text { handled the coronavirus outbreak? }\end{array}$ & $\begin{array}{c}\text { How well has the Scottish Government } \\
\text { handled the coronavirus outbreak? }\end{array}$ \\
\hline Very well & 2 & 20 \\
Fairly well & 17 & 39 \\
Neither well nor badly & 15 & 17 \\
Fairly badly & 24 & 13 \\
Very badly & 39 & 10 \\
Do not know & 2 & 2 \\
(N) & $(1,214)$ & $(1,201)$ \\
\hline
\end{tabular}

Note: Scottish respondents only. Source: BESIP, wave 20-June 2020 (Fieldhouse et al., 2020).

On a 0 to 10 scale, where 0 means to stand for "reduce infections even if it damages the economy" and 10 means "save the economy even if it increases infections," the Scottish public show a mean position of 3.3, that is, the average voter is inclined to the pro-health end of the spectrum. Using the same scale to locate the parties' positions, the Scottish public showed that they had a very different perception of the strategies followed by the government parties in Scotland and the UK. On average, the public placed the SNP at 2.8 on the scale and the Conservative party at 7.1. The party of the Scottish First Minister was much more in tune with the views of the public than the party of the UK Prime Minister.

However, the available data do not show a strong connection between assessments of the coronavirus han- dling and changing views on independence. Table 4 shows independence vote intentions before and after the pandemic outbreak by the public's view of the Scottish government handling of the pandemics. It shows small increases of Yes vote for all assessment categories except for those that judged the management as "very badly" who, logically, became more reluctant to support independence. The last row of the table reveals that the BESIP did not register a significant increase in support for independence in June 2020: Yes support was only 0.7 percentual points higher than a year before. Two reasons may be behind this lack of change. First, the survey's fieldwork may simply be too early to see the full extent of the coronavirus effect on independence support. By June 2020 , Yes had only just begun to creep ahead in the polls.

Table 4. Handling of the coronavirus crisis by the Scottish government and independence voting intentions before and after the pandemic.

\begin{tabular}{lccr}
\hline & Percentage vote intention for Yes, 2019 & Percentage vote intention for Yes, 2020 & $(\mathrm{N})$ \\
\hline Very well & 65.5 & 66.8 & $(310)$ \\
Fairly well & 45.2 & 45.7 & $(560)$ \\
Neither well nor badly & 26.0 & 28.4 & $(250)$ \\
Fairly badly & 16.7 & 17.6 & $(210)$ \\
Very badly & 19.6 & 17.6 & $(148)$ \\
Do not know & 23.3 & 20.0 & $(30)$ \\
Total & 39.3 & 40.0 & $(1,508)$ \\
\hline
\end{tabular}

Note: Scottish respondents that participated in both waves only. Source: BESIP wave 19-December 2019, and wave 20-June 2020 (Fieldhouse et al., 2020). 
Most of the rise came later, peaking in autumn. Second, respondents to the BESIP panel are generally highly politically engaged: On average, wave 20 respondents have answered 9 of the 20 waves and show a mean of 6.8 on an eleven-point political engagement scale. They likely have firmer opinions on the independence issue than the Scottish electorate as a whole. The panel may understate the degree of change present in the population over this period.

\subsection{The Profile of the Pro-Independence Voter}

Table 5 compares the socio-political profile of the independence supporter in 2014 and 2020. Two sociodemographic groups show substantive changes. First, the gender gap has reversed. In 2014, men were more likely to vote Yes than women by 6 percentage points, and other surveys point to even wider differences (Curtice, 2014, 2020). A majority of men supported Yes in 2014, so the No victory appears to rest heavily on the support of women. Women are more risk-averse (Byrnes et al., 1999; Weber et al., 2002), a characteristic that prevents support against uncertain changes (Liñeira \& Henderson, 2021; Verge et al., 2015).

Now, the picture appears to be rather different. Women have increased their support for independence by 6 percentage points and men have dropped their support by 7 points. The gender gap has reversed and now women support independence by 5 percentage points more than men. A possible factor behind the reversion is that Brexit changed the perception of where the risk lies. Back in 2014, the independence proposal was perceived as the riskiest option, mainly due to economic uncertainties (Johns, 2016; Liñeira et al., 2017): 59 per cent of Scottish respondents were unsure about what will happen in the event of Scotland's independence, whereas only 31 per cent thought the same about the prospects of Scotland remaining in the UK (BESIP, May-June 2014,

Table 5. Percentage of independence support by socio-demographics, identities, and political preferences.

\begin{tabular}{|c|c|c|c|}
\hline & 2014 & 2020 & Change \\
\hline \multicolumn{4}{|l|}{ Gender } \\
\hline Women & 44 & 50 & +6 \\
\hline Men & 52 & 45 & -7 \\
\hline \multicolumn{4}{|l|}{ Age groups } \\
\hline $18-24$ & 53 & 63 & +10 \\
\hline $25-39$ & 54 & 59 & +5 \\
\hline $40-59$ & 50 & 52 & +2 \\
\hline $60-64$ & 47 & 43 & -4 \\
\hline 65 and over & 35 & 34 & -1 \\
\hline \multicolumn{4}{|l|}{ Occupation grade } \\
\hline Higher & 45 & 47 & +2 \\
\hline Intermediate & 43 & 44 & +1 \\
\hline Lower & 52 & 49 & -3 \\
\hline \multicolumn{4}{|l|}{ Educational attainment } \\
\hline Lower than secondary education & 46 & 38 & -8 \\
\hline Secondary education & 49 & 46 & -3 \\
\hline Higher education & 47 & 52 & +5 \\
\hline \multicolumn{4}{|l|}{ National identification } \\
\hline Only Scottish & 89 & 89 & 0 \\
\hline More Scottish than British & 60 & 63 & +2 \\
\hline Equally Scottish and British & 19 & 14 & -5 \\
\hline More British than Scottish & 12 & 14 & +2 \\
\hline Only British & 10 & 18 & +8 \\
\hline \multicolumn{4}{|l|}{ General election vote recall } \\
\hline Conservative & 14 & 6 & -8 \\
\hline Labour & 42 & 32 & -10 \\
\hline Liberal Democrat & 42 & 17 & -25 \\
\hline SNP & 85 & 87 & +2 \\
\hline \multicolumn{4}{|l|}{ EU membership referendum vote } \\
\hline Leave/Stay out & 42 & 22 & -20 \\
\hline Remain/Re-join & 52 & 63 & +11 \\
\hline
\end{tabular}

Note: Independence support is measured through a vote recall question in 2014 and through a vote intention question in 2020. Source: BESIP wave 3-September/October 2014, and wave 20-June 2020 (Fieldhouse et al., 2020). 
wave 2). By contrast, uncertainty was on the Leave side in the EU referendum: 38 per cent of Scottish respondents were unsure about what would happen to the UK in the event of Leave, whereas only 23 per cent thought the same about Remain (BESIP, May-June 2016, wave 8).

Meanwhile, the age profile of the pro-independence and pro-union sides works to the advantage of the former. The link between age and independence support is not new: Back in 2014 older cohorts opposed independence, whereas younger cohorts were more divided. Now, support for independence is majoritarian for all groups under 60 years old. Support has particularly increased among people in their teens, twenties, and thirties. The overwhelming support to Remain in the EU by younger cohorts seems the likeliest factor behind this change (Fieldhouse et al., 2019, pp. 163-187). Again, the cross-cutting debates of secession and EU membership have changed the profile of the pro-independence voter.

Independence support by education and occupation levels show smaller amounts of change. However, they significantly changed in the same direction. Education was not a huge differential factor in 2014, but it appears to be now: Those with higher educational attainment have increased their support for independence, whereas the opposite has occurred among those with fewer years of academic education. A similar story, with smaller differences, has happened within the different occupation groups. In 2014, independence only won among those with lower occupation grades according to the National Statistics Socio-Economic Classification. In 2020, independence does not win in any occupation groups, but independence support has increased in the higher occupation grades.

National identifications keep being strongly related to independence support, but the direction and strength of this relationship has not changed since 2014. The only remarkable change is related to those who identify with Britain rather than Scotland-a category mainly selected by Scottish residents with English background (Bond, 2000,2006 ) - who almost doubled their level of independence support in 2020.

However, the biggest change is related to the growing association between political preferences and independence support. Table 1 shows that the 2014 referendum reinforced the relationship between party choice and independence choice. Table 5 shows that the relationship has become stronger since 2014. It also illustrates the cross-cutting of constitutional debates. Back in 2014, the difference between Eurosceptics' and Europhiles' support for independence was 10 percentage points. Now it is 41 points: 63 per cent of support for independence by those who favour to re-join the EU and only 22 per cent among those who wish to stay out.

\section{Conclusions}

In this article, I have examined the factors that explain secession preferences in Scotland and how they have been affected by three external shocks: the 2014 independence referendum, the 2016 EU membership referendum, and the outbreak of the Covid-19 pandemic.

The independence referendum was a critical juncture for Scottish politics. Independence used to be a minority cause and it has become a mainstream option. It transformed the party landscape and made the SNP a dominant force that comes first at both general and Scottish Parliament elections. It also increased the saliency of the independence dimension. This can be observed in the closer alignment between party choice and independence support, but also in the stronger association between secession determinantssuch as national identification, partisanship, and economic evaluations-and secession preferences.

Brexit changed the nature of the independence debate. Both debates show similar arguments about the implications of what is proposed for the economy, sovereignty, and influence in the world, and both also touch upon people's sense of identity and how they would like that to be reflected in the arrangements under which they are governed. The two debates were initially separated but they are now intertwined. Back in 2014, there was no significant correlation between the people's position on one issue over the other, but this is not the case anymore. Though it is a far from perfect correlation-there are four distinct electoral constituencies in Scotland that result from the cross-cutting of these two debates-the two issues are not orthogonal: Those who support Scotland's independence tend to favour re-joining the EU. The realignment was evident in 2016 , but it was later, when the terms of Brexit became clearer-a UK out of the single market and the customs union - that it started to pay for the independence cause. Much of the rise in independence support that started in the second semester of 2019 draws from those who are favourably disposed towards the EU.

Brexit has therefore weakened the perceived merits of the Union in the eyes of a modest but significant body of voters in Scotland. Remain voters are far from all being advocates of a highly integrated EU, but many view Brexit with concern for the country's prospects and, particularly, the economic future. For some of these voters, independence in the EU looks more attractive than being part of a UK out of the EU. The economic concern that prevented some voters to support independence in 2014 has changed sides to a certain extent. Brexit has also confirmed that Scotland's can be easily overturned by England's electoral will, which has led some voters to embrace the independence project.

However, none of this means that Scotland is now set firmly on a path that will eventually lead to independence. Many of the potential implications of an independent Scotland in the EU while the rest of the UK is outside, ranging from the consequences of a single market border between England and Scotland to the relative merits of easy access to the EU single market as opposed to the internal UK market, have yet to be 
debated. These debates may change minds in either direction, as the 2014 referendum campaign illustrates. Brexit has changed the levels of support for secession, but it has also changed the meaning of Scotland's independence: Secession is now a more disruptive project than in 2014 when both England and Scotland were in the EU. The impact of Brexit on Scotland's chances to secede is far from being determined.

By contrast, I did not find strong evidence that the Covid pandemic was behind the last surge in independence support. Covid did not lead the Scottish public to support a valence secession, that is, one based on the view that Scotland would govern itself more effectively as an independent country. It seems that the different handling of the pandemic encouraged a proindependence surge during the second semester of 2020, but the gap had already narrowed by early 2021 . The fact that the pandemic did not produce lasting effects on secession preferences does not deny its nature as a voting shock, though its potential for change seems to have resulted in just a temporary bump on independence voting intentions. If it produced an impact, it was a short term one, and short term impacts only determine referendum results if they happen at the crucial time of an independence referendum campaign.

However, the handling of the pandemic might lead the public to update its view of the SNP, which may have gained a more competent party image as a result. In the short term, this could have facilitated the party's victory in the May 2021 Scottish Parliament elections. In the long-term, it may cement the idea that Scottish governments led by the SNP handle things differently than UK governments. If this should be the case, valence considerations could have lasting implications for both the SNP and its pro-independence project.

\section{Conflict of Interests}

The author declares no conflict of interests.

\section{References}

Alesina, A., \& Spolaore, E. (2005). The size of nations. MIT Press.

Bartkus, V. O. (1999). The dynamic of secession. Cambridge University Press.

Berger, M. M., Munger, M. C., \& Potthoff, R. F. (2000). The Downsian model predicts divergence. Journal of Theoretical Politics, 12(2), 228-240.

Blais, A., Martin, P., \& Nadeau, R. (1995). Attentes économiques et linguistiques et appui à la souveraineté du Québec: Une analyse prospective et comparative [Economic and linguistic expectations and support to the sovereignty of Quebec: A prospective and comparative analysis]. Canadian Journal of Political Science/Revue Canadienne de Science Politique, 28(4), 637-657.

Blais, A., \& Nadeau, R. (1992). To be or not to be sovereignist: Quebeckers' perennial dilemma. Canadian Public Policy, 18(1), 89-103.

Bond, R. (2000). Squaring the circles: Demonstrating and explaining the political 'non-alignment' of Scottish national identity. Scottish Affairs, 32(1), 15-36.

Bond, R. (2006). Belonging and becoming: National identity and exclusion. Sociology, 40(4), 609-626.

Bond, R. (2015). National identities and the 2014 independence referendum in Scotland. Sociological Research Online, 20(4), 92-104.

Byrnes, J. P., Miller, D. C., \& Schafer, W. D. (1999). Gender differences in risk taking: A meta-analysis. Psychological Bulletin, 125(3), 367-383.

Campbell, A., Converse, P. E., Miller, W. E., \& Stokes, D. E. (1960). The American voter. John Wiley \& Sons.

Christin, T., Hug, S., \& Sciarini, P. (2002). Interests and information in referendum voting: An analysis of Swiss voters. European Journal of Political Research, 41(6), 759-776.

Clarke, H. D., Kornberg, A., \& Stewart, M. C. (2004). Referendum voting as political choice: The case of Quebec. British Journal of Political Science, 34(2), 345-355.

Curtice, J. (2006). Is Holyrood accountable and representative? In C. Bromley, J. Curtice, D. McCrone, \& A. Park (Eds.), Has devolution delivered? (pp. 90-108). Edinburgh University Press.

Curtice, J. (2014, September 26). So who voted yes and who voted no? What Scotland thinks. https:// whatscotlandthinks.org/2014/09/voted-yes-voted

Curtice, J. (2015a). How Scotland voted: Economic perceptions in the Scottish independence referendum. International Public Policy Institute Policy.

Curtice, J. (2015b). Has the referendum campaign made a difference? ScotCen.

Curtice, J. (2019, September 17). An unresolved question? The independence debate five years on. What Scotland Thinks. https://whatscotlandthinks. org/2019/09/an-unresolved-question-theindependence-debate-five-years-on

Curtice, J. (2020, October 20). Brexit, coronavirus and the economy: Three key issues in the independence debate. What Scotland Thinks. https://whatscotland thinks.org/2020/10/brexit-coronavirus-and-theeconomy-three-key-issues-in-the-independencedebate

Curtice, J. (2021, February 26). Has the constitutional wind changed direction? What Scotland Thinks. https://whatscotlandthinks.org/2021/02/has-theconstitutional-wind-changed-direction

Curtice, J., \& Montagu, I. (2020). Is Brexit fuelling support for independence? ScotCen.

Dalton, R. J. (1999). Political support in advanced democracies. In P. Norris (Ed.), Critical citizens: Global support for democratic government (pp. 57-77). Oxford University Press.

de Vreese, C. H. (Ed.). (2007). The dynamics of referendum campaigns: An international perspective. Palgrave Macmillan. 
Eckles, D. L., Kam, C. D., Maestas, C. L., \& Schaffner, B. F. (2013). Risk attitudes and the incumbency advantage. Political Behavior, 36(4), 731-749.

Erikson, R. S., \& Wlezien, C. (2012). The timeline of presidential elections. How campaigns do (and do not) matter. University of Chicago Press.

Fieldhouse, E., Green, J., Evans, G., Mellon, J., Prosser, C., de Geus, R. A., Bailey, J., Schmitt, H., \& van der Eijk, C. (2020). British election study combined wave 1-20 internet panel [Data set]. https://www.british electionstudy.com/data-object/british-electionstudy-combined-wave-1-20-internet-panel

Fieldhouse, E., Green, J., Evans, G., Mellon, J., Prosser, C., Schmitt, H., \& van der Eijk, C. (2019). Electoral shocks: The volatile voter in a turbulent world. Oxford University Press.

Gelman, A., \& King, G. (1993). Why are American presidential election campaign polls so variable when votes are so predictable? British Journal of Political Science, 23(4), 409-451.

Gourevitch, P. A. (1979). The reemergence of "peripheral nationalisms": Some comparative speculations on the spatial distribution of political leadership and economic growth. Comparative Studies in Society and History, 21(3), 303-322.

Guinjoan, M. (2021). Who backs separation? An empirical assessment of the objective and subjective markers of identity in support for secession in Catalonia. Publius: The Journal of Federalism. Advance online publication. https://doi.org/10.1093/publius/ pjab027

Hechter, M. (2000). Containing nationalism. Oxford University Press.

Henderson, A. (2014). The myth of meritocratic Scotland: Political cultures in the UK. In P. Cowley \& R. Ford (Eds.), Sex, lies and the ballot box: 50 things you need to know about British elections (pp. 103-107). Biteback.

Henderson, A., \& Mitchell, J. (2018). Referendums as critical junctures? Scottish voting in British elections. Parliamentary Affairs, 71(Suppl. 1), 109-124.

Hierro, M. J. (2012). Change in national identification. A study of the Catalan case [Doctoral thesis, Universidad Autónoma de Madrid]. Repositorio de Datos de Investigación UAM. https://repositorio.uam.es/ handle/10486/10285

Hierro, M. J., \& Queralt, D. (2021). The divide over independence: Explaining preferences for secession in an advanced open economy. American Journal of Political Science, 65(2), 422-442.

Hooghe, L., \& Marks, G. (2005). Calculation, community and cues public opinion on European integration. European Union Politics, 6(4), 419-443.

Howe, P. (1998). Rationality and sovereignty support in Quebec. Canadian Journal of Political Science, 31(1), 31-59.

Johns, R. (2016). It wasn't 'The Vow' wot won it: The Scottish independence referendum. In P. Cowley \&
R. Ford (Eds.), More sex, lies and the ballot box: Another 50 things you need to know about elections (pp. 185-189). Biteback.

Johns, R., \& Mitchell, J. (2016). Takeover: Explaining the extraordinary rise of the SNP. Biteback.

Kam, C. D., \& Simas, E. N. (2010). Risk orientations and policy frames. The Journal of Politics, 72(2), 381-396.

Keating, M. (Ed.). (2017). Debating Scotland: Issues of independence and union in the 2014 referendum. Oxford University Press.

LeDuc, L. (2003). The politics of direct democracy: Referendums in global perspective. Broadview Press.

Liñeira, R., \& Henderson, A. (2021). Risk attitudes and independence vote choice. Political Behavior, 43(2), 541-560.

Liñeira, R., Henderson, A., \& Delaney, L. (2017). Voter's response to the campaign. In M. Keating (Ed.), Debating Scotland: Issues of independence and union in the 2014 referendum. Oxford University Press.

Lluch, J. (2014). Visions of sovereignty: Nationalism and accommodation in multinational democracies. University of Pennsylvania Press.

Lodge, M., \& Taber, C. S. (2013). The rationalizing voter. Cambridge University Press.

Mattern, J. (2019). The employment of the plebiscite in the determination of sovereignty. Johns Hopkins University Press.

McGann, A., Dellepiane-Avellaneda, S., \& Bartle, J. (2019). Parallel lines? Policy mood in a plurinational democracy. Electoral Studies, 58, 48-57.

Medrano, J. D., \& Gutiérrez, P. (2001). Nested identities: National and European identity in Spain. Ethnic and Racial Studies, 24(5), 753-778.

Mendelsohn, M. (2003). Rational choice and sociopsychological explanation for opinion on Quebec sovereignty. Canadian Journal of Political Science, 36(3), 511-537.

Mitchell, J., \& Henderson, A. (2020). Tribes and turbulence: The 2019 UK general election in Scotland. Parliamentary Affairs, 73(Suppl. 1), 142-156.

Morgenstern, S., \& Zechmeister, E. (2001). Better the devil you know than the saint you don't? Risk propensity and vote choice in Mexico. The Journal of Politics, 63(1), 93-119.

Muñoz, J., \& Tormos, R. (2015). Economic expectations and support for secession in Catalonia: Between causality and rationalization. European Political Science Review, 7(2), 315-341.

Nadeau, R., Martin, P., \& Blais, A. (1999). Attitude towards risk-taking and individual choice in the Quebec referendum on sovereignty. British Journal of Political Science, 29(3), 523-539.

Paterson, L., Brown, A., Curtice, J., Hinds, K., McCrone, D., Park, A., Sproston, K., \& Surridge, P. (2001). New Scotland, new politics? Edinburgh University Press.

Phillips, D., Curtice, J., Phillips, M., \& Perry, J. (2018). British social attitudes 35 . NatCen.

Qvortrup, M. (2014). Referendums and ethnic conflict. 
University of Pennsylvania Press.

Redlawsk, D. P. (2002). Hot cognition or cool consideration? Testing the effects of motivated reasoning on political decision making. The Journal of Politics, 64(4), 1021-1044.

Sambanis, N., \& Milanovic, B. (2014). Explaining regional autonomy differences in decentralized countries. Comparative Political Studies, 47(13), 1830-1855.

ScotCen Social Research. (2013). Scottish social attitudes survey, 2012. [Data set]. UK Data Service. http://doi. org/10.5255/UKDA-SN-7338-2

ScotCen Social Research. (2016). Scottish social attitudes survey, 2014. [Data set]. UK Data Service. http://doi. org/10.5255/UKDA-SN-7599-2

Scottish Government. (2013). Scotland's future. Your guide to an independent Scotland.

Serrano, I. (2020). Ethnic alignment in divided regions: Individual and contextual factors. Territory, Politics, Governance, 8(4), 532-552.

Sorens, J. (2005). The cross-sectional determinants of secessionism in advanced democracies. Comparative Political Studies, 38(3), 304-326.
Sorens, J. (2012). Secessionism: Identity, interest, and strategy. McGill-Queen's University Press.

Tajfel, H. (1974). Social identity and intergroup behaviour. Social Science Information, 13(2), 65-93.

Tomz, M., \& Van Houweling, R. P. (2009). The electoral implications of candidate ambiguity. American Political Science Review, 103(1), 83-98.

Verge, T., Guinjoan, M., \& Rodon, T. (2015). Risk aversion, gender, and constitutional change. Politics \& Gender, 11(3), 499-521.

What Scotland Thinks. (n.d.). How would you vote in a Scottish independence referendum if held now? (asked after the EU referendum) [Data set]. What Scotland Thinks. https://whatscotlandthinks. org/questions/how-would-you-vote-in-the-in-ascottish-independence-referendum-if-held-now-ask

Weber, E. U., Blais, A.-R., \& Betz, N. E. (2002). A domainspecific risk-attitude scale: Measuring risk perceptions and risk behaviors. Journal of Behavioral Decision Making, 15(4), 263-290.

Zaller, J. R. (1992). The nature and origins of mass opinion. Cambridge University Press.

\section{About the Author}

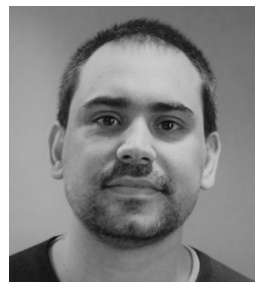

Robert Liñeira is lecturer in politics at the University of Glasgow. His research interests deal with public opinion, political behaviour, and direct democracy, particularly on issues related to territorial politics. His work has been published in journals such as Political Behavior, Party Politics, JCMS: Journal of Common Market Studies and Publius: The Journal of Federalism, amongst others. 